Test your Skill

3 minutes.

Double-line spacing.

\section{LESSON 64}

\section{Tabulation 24}

PAPER: A5 $(210 \times 148 \mathrm{~mm})$.

TARGET TIME: 15 minutes.

\section{Letter 31}

PAPER: Suitable.

TARGET TIME: 12 minutes.

This personal business letter is the reply to the last letter in Lesson 58.

Address a sheet of $\mathrm{A} 6$ paper as an envelope.

\section{Letter 32}

PAPER: Suitable.

TARGET TIME: 10 minutes.

This is the reply to the second letter in Lesson 56.

Take a carbon copy, and address a sheet of A6 paper as an envelope.

UNIT 16
When you take out an insurance policy you are asked to fill in what is known as a proposal form. This form requires you to give certain information concerning yourself and what you intend protecting should your proposal be accepted. A contribution, called a premium, to the pool from which insurance claims are paid out must then be paid and you know you are given temporary cover when a cover note is issued. Finally you will be given the certificate of insurance and the policy itself.

\begin{tabular}{|c|c|c|}
\hline Destes & Typing Chairs & Fling Cabincts \\
\hline $\begin{array}{l}\text { Double Pedestal } \\
\text { Single Pedestal } \\
\text { secretarial Major } \\
\text { secretarial Minor } \\
\text { Gouly Major } \\
\text { Golly Minor } \\
\text { Teakmaster office } \\
\text { Teakmaster Executind }\end{array}$ & $\begin{array}{l}\text { Sit Rite } \\
\text { Posture } 5 \\
\text { Super } 2 \\
\text { Secretarial I } \\
\text { Secretarial } 2 \\
\text { Devi } \\
\text { Devi Masci } \\
\text { Chindit }\end{array}$ & $\begin{array}{l}\text { Continuous } \\
\text { Fillit A } \\
\text { Fillit B } \\
\text { Vercical } \\
\text { Horizontal } \\
\text { Lateral } \\
\text { Scorit } \\
\text { Jombo }\end{array}$ \\
\hline
\end{tabular}

From: 18 Coombe House, Aboyne, Aberdean shive. AB5 29H Today's date To: Tape Technical Services, 67 rilbrook Road, Glasgow. For she attention of $M$. Duckhouse Deas Sirs. Thank you fot yow lettor and the enclosed tape. (Paragraph) I tegret to inform you ohat she tape is unsatisfactory as the hole in the contre of the sporl is too small fot my dictation machine. (Paragraph) will yol ploase sand me a tape on a spool with a centre diameter of $10 \mathrm{~mm}$ instead of this one eirth a $6 \mathrm{~mm}$ diameter hole. Youls sincerly Robost Gotterill

Michael Ward, Esq. 6 High Streat, Norton, BATM. BAL 8 No Dear Mr. Ward. We thank you for your recent letter and aqree that the bill was for a Warranty Clain and was charged to your account in error. This has now bean put right. (Paragrph) Please accept our apologies for the error and ary inconvenience camed to you. Yours faithfully, sQunRE DEA GARAGE J. S. Heynes Accountant 